\title{
Effect of Spindle Unit Extrusion on Stability of Machining Process
}

Zdenek Fiala, Ales Jaros, Josef Sedlak, Ladislav Kolar, Vendula Blazkova

Department of Machining Technology, Institute of Manufacturing Technology, Faculty of Mechanical Engineeering, Brno University of Technology, Technicka 2896/2, Brno 616 69, Czech Republic.

E-mail: yfiala18@stud.fme.vutbr.cz, yjaros18@stud.fme.vutbr.cz, sedlak@fme.vutbr.cz, ykolar26@stud.fme.vutbr.cz, ysveco01@stud.fme.vutbr.cz

Dynamic characteristics of a machine-tool-workpiece system are not constant during machining, but they can be changed by a variable spindle position, a rising tool wear or a gradual change of a workpiece geometry. This paper deals with an influence of spindle unit extrusion on stability of a machining process. Two milling cutters with different rigidity, flexible and stiff, were used for experimental machining at three axis milling machines. Clamped milling cutters were extracted systematically and a frequency response function was measured simultaneously. Reached data (natural frequency and dynamic compliance) were used for finding a correlation between dynamic parameters and extrusion of the spindle. Critical extrusion of the spindle unit was predicted by an experimental measurement and an axial depth of cut thresholds was established for the stable machining.

Keywords: Vibration, spindle, stability, extrusion, dynamic compliance

\section{Acknowledgement}

This research was supported and co-financed from the project named "Excellent Young Scientists at Brno University of Technology in Brno" - register number CZ.1.07/2.3.00/30.0039.

\section{References}

[1] PALPANDIAN, P., PRABHU RAJA, V., SATISH BABU. S. (2013). Stability Lobe Diagram for High Speed Machining Processes:Comparison of Experimental and Analytical Methods - A Review. In: International Journal of Innovative Research in Science, Vol. 2, Issue 3, pp. 1-6. ISSN: 2319-8753.

[2] CAO, H., LI, B., HE, Z. (2012). Chatter Stability of Milling with Speed-varying Dynamics of Spindles. In: International Journal of Machine Tools and Manufacture, Vol. 52, Issue 1, pp. 50-58.

[3] TLUSTY, J., POLACEK, M. (1963). Stability of Machine Tool Against Self Excited Vibration in Machining. In: ASME Prod. Engg. Res. Conf., Pittsburgh, Vol. 1, pp. 454-465.

[4] ALTINTAS, Y., BUDAK, E. (1995) Analytical Prediction of Stability Lobes in Milling. In: CIRP Annals-Manufacturing Technology, Vol. 44, Issue 1, pp. 357-362.

[5] INSPERGER, T., MANN, B. P., STEPAN G., et al. (2003). Stability of Up-milling and Down-milling, Part 1: Alternative Analytical Methods. In: International Journal of Machine Tools and Manufacture, Vol. 43, Issue 1, pp. 25-34.

[6] TLUSTY, J., KROENIGSBERGER, F. (1970). Specifications and Tests of Metal Cutting Machine Tools. In: UMIST, Manchester, England.

[7] TLUSTY, J., POLACEK, M. (1963). Stability of Machine Tool Against Self Excited Vibration in Machining. In: ASME Prod. Engg. Res. Conf., Pittsburgh, Vol. 1, pp. 454-465.

[8] SCHMITZ, T. L., SMITH, K. S. (2009) Machining Dynamics: Frequency Response to Improved Productivity. Springer Science, ISBN 978-0-387-09644-5.

[9] AHMADI, K., ISMAIL, F. (2012). Investigation of Finite Amplitude Stability Due to Process Damping in Milling. In: Fifth CIRP Conference on High Performance Cutting. Vol. 1, pp. 60-65.

[10]SCHMITZ, T. L., DAVIES, M. A., MEDICUS, K., et al. (2001). Improving High-speed Machining Material Removal Rates by Rapid Dynamic Analysis. In: Cirp Annals- Manufacturing Technology, Vol. 50, Issue 1, pp. 263268.

[11] GAGNOL, V., BOUZGARrou, B, C., Ray, P., et al.(2007). Stability-based Spindle Design Optimization. In: ASME Journal of Manufacturing Science and Engineering, Vol. 129, Issue 2, pp. 407-415. 
[12] GAGNOL, V., BOUZGARROU, B, C., Ray, P., et al.(2007). Model-based Chatter Stability Prediction for Highspeed Spindles. In: International Journal of Machine Tool and Manufacture, Vol. 47, Issues 7-8, pp. 1176-1186.

[13] SHUYUN, J., SHUFEI, Z. (2010). Modelling Approach for Analysis and Improvement of Spindle-drawbar-bearing Assembly Dynamics. In: International Journal of Machine tool and Manufacture, Vol. 50, Issue 1, pp. 131142 .

[14] ZAGHBANY, I., SONGMENE, V. (2009). Estimation of Machine-tool Dynamic Parameters during Machining Operation through Operational Modal Analysis. In: International Journal of Machine Tools and Manufacture, Vol. 49, Issues 12-13, pp. 947-957.

[15] SCHMITZ, T, L., ZIEGERT, J., STANISLAUS, C. (2004). Method for Predicting Chatter Stability for Systems with Speed-dependent Spindle Dynamics. In: Society of Manufacturing Engineers Technical Paper TPO4PUB182, Transactions of NAMRI/SME, Vol. 32, pp. 17-24.

[16] XU, J., GU, L., LUO, S. (2014). Dynamic Analysis for High-speed Cutters of Five-axis CNC Milling Machine. In: Manufacturing Technology, Vol. 14, pp. 643-650. ISSN 1213-2489.

[17] FABIAN, S., SALOKYOVA, S., JACKO, P. (2010). Experimental Verification of Frequency Spectrum of Unwears and Wears Guidance Tube on Technological Head Vibrations Creation in Production System with AWJ Technology. In: Manufacturing Technology, Vol. 12, pp. 105-108. ISSN 1213-2489.

[18] GAGNOL, V., LE, T., RAY, P. (2011). Modal Identification of Spindle-tool Unit in High-speed Machining. In: Mechanical Systems and Signal Processing, Vol. 25, Issue 7, p. 2388-2398

ABELE, E., FIEDLER, U. (2004). Creating Stability Lobe Diagrams during Milling. In: Cirp Annals- Manufacturing Technology, Vol. 53, Issue 1, pp. 309-312. 